\title{
First record of the freshwater sawfish, Pristis microdon, from southwestern Australian waters
}

\author{
Justin A. Chidlow \\ Department of Fisheries, Western Australian Marine Research Laboratories, \\ PO Box 20, North Beach, Western Australia 6920 \\ Email: jchidlow@fish.wa.gov.au
}

Sawfishes (family Pristidae) are large (up to $7 \mathrm{~m}$ ) modified batoids with a blade-like snout edged with pairs of rostral teeth. They occur worldwide in sub-tropical and tropical shallow coastal sea, estuaries and freshwater systems (Last and Stevens 1994; Compagno and Last 1998). There are between five and seven recognised species worldwide, with five species represented in Australian waters (Last and Stevens 1994). Sawfish populations have been extirpated from many parts of their original global range by gillnetting and trawling and are easily entangled in nets by their toothed rostra (Simpfendorfer 2000). The little that is known about the biology of sawfish suggests they have low rates of reproduction (Tanaka 1991; Compagno and Last 1998; Wilson 1999; Simpfendorfer 2000; Thorburn et al. 2004). This combined with their susceptibility to fishing gear, make sawfish a high risk species and all have subsequently been listed globally as critically endangered under the IUCN Red List Assessment 2006 (Compagno et al. 2006).

\section{Pristis microdon Latham, 1794}

Pristis microdon is a medium to large sawfish that in Australia grows to at least $361 \mathrm{~cm}$ TL (Tanaka 1991), but is reported to reach up to $700 \mathrm{~cm} \mathrm{TL}$ in other locations (Last and Stevens 1994). They are born at around $50 \mathrm{~cm}$ in length after a five month gestation period, with litter sizes ranging between 1 and 12 (Wilson 1999). In the western Atlantic $P$. microdon matures at between $240 \mathrm{~cm}$ and $300 \mathrm{~cm} \mathrm{TL}$ (Compagno and Last 1998). Tanaka (1991) reported two male specimens from New Guinea, one measuring $247 \mathrm{~cm}$ that was immature and a $361 \mathrm{~cm}$ specimen that was mature. In Australian waters, $P$. microdon feeds on fish such as catfish, small crustaceans and molluscs (Allen 1982; Cliff and Wilson 1994; Pogonoski et al. 2002; Thorburn et al. 2004).

Pristis microdon occurs inshore and in intertidal areas and is usually found in freshwater drainages, lakes and estuaries where it can penetrate as far as $400 \mathrm{~km}$ from the coast (Morgan et al. 2004). In the Indo-West Pacific it ranges from New Guinea, SE Asia, northern Australia and west to South Africa
(Last and Stevens 1994; Compagno and Last 1998). Pristis microdon may also occur in the Atlantic and eastern Pacific if $P$. perotteti Müller \& Henle, 1841 and $P$. zephyreus Jordan \& Starks in Jordan, 1895 are synonymised with this species (Compagno and Last 1998). In Australia, the freshwater sawfish is known to occur in the Ord, Durack and Fitzroy Rivers (Western Australia), the Adelaide, Victoria and Daly Rivers (Northern Territory), and the Gilbert, Mitchell, Norman and Leichhardt Rivers (Queensland) (Last and Stevens 1994; Pogonoski et al. 2002; Thorburn et al. 2004). Only recently has $P$. microdon been reported from marine waters (Thorburn et al. 2004).

\section{Southwestern Australian P. microdon}

A female $P$. microdon was captured by a commercial shark fisher operating demersal gillnets in southwestern Australian waters on the $5^{\text {th }}$ of February 2003. The capture location was approximately six miles east of Cape Naturaliste $\left(33^{\circ} 31^{\prime} \mathrm{S}, 115^{\circ} 07^{\prime} \mathrm{E}\right)$ in $32 \mathrm{~m}$ of water. The sawfish was estimated to be $3.5 \mathrm{~m}$ in length TL when landed and appeared to be healthy. The specimen was processed and the fisher retained the remaining trunk, fins and saw. I positively identified the processed sawfish as $P$. microdon using an identification key provided by Last and Stevens (1994).

The partial length (origin of the first dorsal fin to the insertion point of the second dorsal fin) was $95 \mathrm{~cm}$ (approximate as the trunk had been cut in half). The rostral saw length was $79 \mathrm{~cm}$ with 19 pairs of teeth that extended to the basal quarter of the saw (Figure 1). The interspace between rostral teeth at the base of the saw was $4 \mathrm{~cm}$, and $3 \mathrm{~cm}$ between the teeth at the tip of the saw (Figure 1). A groove was present along the posterior margin of all rostral teeth. The origin of the first dorsal-fin was located anterior to the pelvic-fin origin and the height of the first dorsal-fin was $32 \mathrm{~cm}$. The second dorsal-fin height was $31 \mathrm{~cm}$. The ventral lobe of the caudal-fin was small, but distinct. The upper and lower postrentral caudal-fin margins measured $44.5 \mathrm{~cm}$ and $11.5 \mathrm{~cm}$ respectively. 


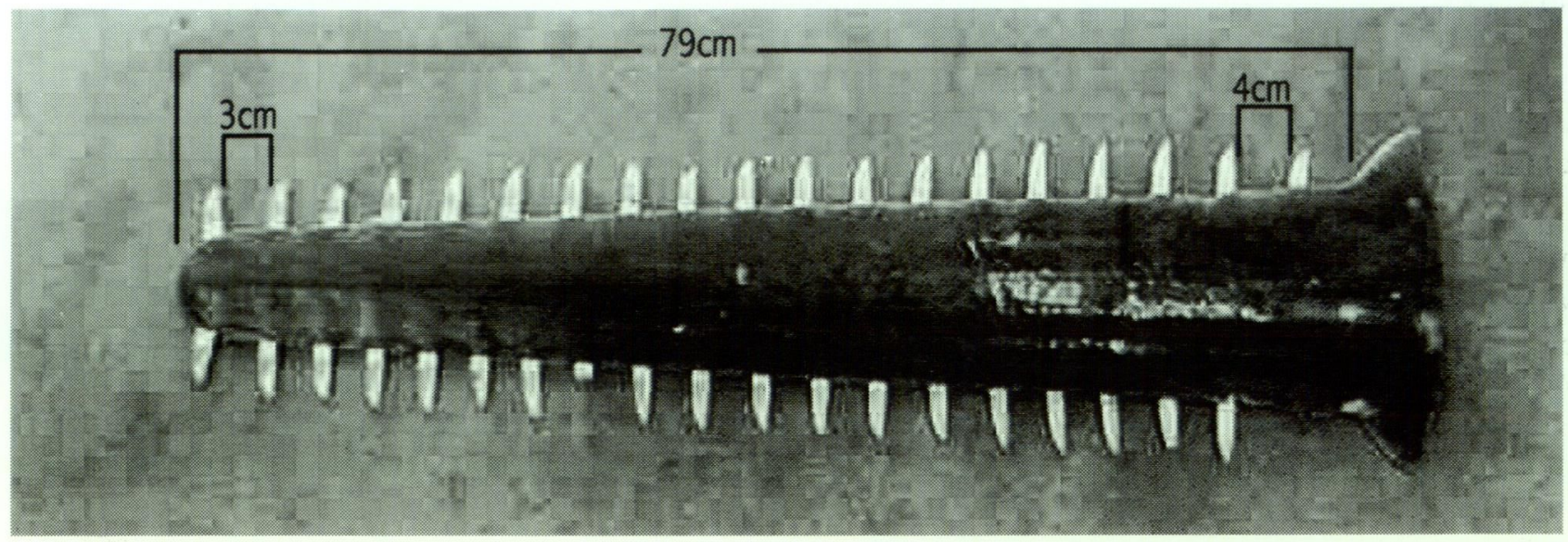

Figure 1 Rostral saw from a female Pristis microdon, measuring approximately $350 \mathrm{~cm}$ in total length, captured off Cape Naturaliste, Western Australia. See text for description of measurements.

This record of $P$. microdon from southwestern Australia extends the range of the species approximately $1600 \mathrm{~km}$ south of its previously known southern limit, Cape Keraudren, Western Australia (Thorburn et al. 2004) and provides further confirmation that $P$. microdon utilizes marine waters.

\section{ACKNOWLEDGEMENTS}

I wish to thank J. Nelson who thoughtfully informed the Shark Research Section, Department of Fisheries WA of the capture, and provided assistance in identifying and collecting data from the specimen. I would also like to thank P. Last from CSIRO Marine Research, Hobart, R. McAuley from Department of Fisheries WA, Perth and C. Simpfendorfer from the Mote Marine Laboratory, Florida for their assistance in positively identifying the specimen.

\section{REFERENCES}

Allen, G.R. (1982). A field guide to inland fishes of Western Australia. Western Australian Museum, Perth, Western Australia. 86pp.

Cliff, G. and Wilson, G. (1994). Natal sharks board's guide to sharks and other marine animals. Natal Sharks Board, p33.

Compagno, L.J.V. and Last, J.D. (1999). Pristiformes: Pristidae. In K.E. Carpenter and V.H. Niem (eds). FAO species identification guide for fishery purposes. The living marine resources of the Western Central Pacific. Volume 3. Batoid fishes, chimaeras and bony fishes part 1 (Elopidae to Linophrynidae). Pp. 14101417. FAO, Rome.

Compagno, L.J.V., Cook, S.F. and Fowler, S.L. (2006). Pristis microdon. In IUCN 2006 IUCN Red List of Threatened Species.

Jordan, D.S. and Starks, E.C. (1895). In The fishes of Sinaloa. D.S. Jordan. Proceedings of the Califfornia Academy of Sciences (Ser. 2) 377-514.
Last, P.R. and Stevens, J.D. (1994). Sharks and rays of Australia. CSIRO, Melbourne, 513 pp.

Latham, J. (1794). An essay on the various species of sawfish. Transactions of the Linnean Society of London 2 (25): 273-282.

Morgan, D.L., Allen, M.G., Bedford, P. and Horstman, M. (2004). Fish fauna of the Fitzroy River in the Kimberley region of Western Australia - including Bunuba,Gooniyandi, Ngarinyin, Nyikina and Walmajarri Aboriginal names. Records of the Western Australian Museum 22:147-161.

Müller, J and Henle, F.G.J. (1841). Systematische Beschreibung der Plagiostomen Berlin. Plagiostomen $\mathrm{i}-\mathrm{xxii}+1-200$.

Pogonoski, J.J., Pollard, D.A. and Paxton, J.R. (2002). Conservation overview and action plan for Australian threatened and potentially threatened marine and estuarine fishes. Environment Australia, February 2002.

Simpfendorfer, C.A. (2000). Predicting population recovery rates for endangered western Atlantic sawfishes using demographic analysis. Environmental Biology of Fishes 58: 371-377.

Tanaka, S. (1991). Age estimation of freshwater sawfish and sharks in northern Australia and Papua New Guinea. The University Museum, University of Tokyo. Nature and Culture 3: 71-82.

Thorburn, D., Morgan, D., Gill, H., Johnson, M., WallaceSmith, H., Vigilante, T., Gorring, A., Croft, I. and Fenton, J. (2004). Biology and cultural significance of the freshwater sawfish (Pristis microdon) in the Fitzroy River, Kimberley, Western Australia. Report to the Threatened Species Network 2004. 57 pp.

Thorson, T.B. (1982). The impact of commercial exploitation on sawfish and shark populations in Lake Nicaragua. Fisheries 7(2): 2-10.

Wilson, D. (1999). Freshwater sawfish Pristis microdon. Australia New Guinea Fishes Associations' A-Z notebook of native freshwater fish. ANGFA Bulletin 41.

Manuscript received 23 August 2004; accepted 3 August 2006 


\section{Guide to Authors}

\section{Subject Matter:}

Reviews, observations and results of research into all branches of natural science and human studies will be considered for publication. However. emphasis is placed on studies pertaining to Western Australia. Longer papers will be considered for publication as a Supplement to the Records of the Westem Australian Muserm. Short communications should not normally exeeed three yyped pages and this category of paper is intended to accommodate observations, results or new records of significance. that otherwise might not get into the literature, or for which there is a particular urgency for publication. All material must be original and not have been published clsewhere.

\section{Presentation:}

Authors are advined to follow the layout and style in the most recent issue of the Records of the Hewem Australian Musem including headings. tables, illustrations and references.

The title should be concise. informative and contain key words necessary for retrieval by modern searching techniques. An abridged title not exceeding 50 letter spaces) should be included for use as a running head

An abstract must be given in full length papers but not short communications. summarizing the scope of the work and principal findings. It should nomally not exceed $2 \%$ of the paper and should be suitable for reprinting in reference periodicals

The International System of units should be used.

Numbers should be spelled out from one to nine in descriptive text: flgures used for 10 or more. For associated groups. figures should be used consistently. e.g. 5 to 10. not five to 10

Spelling should follow the Combise Orford Dirtionam

Systematic papers must conform with the Internationat Codes of Botanical and Zoological Nomenclature and, as far as possible. With their recommendations.

Synonymies should be given in the shont form (taxom. atuthor. date, page) and the full reference cited at the end of the paper. All citations, including those associated with seientific names. must bo included in the references

\section{Manuscripts:}

The original and two copies of manuscripts and figures should be submitted to the Editor. c/ Publications Department. Western Australian Muscum. Locked Bag 49. Welshpool DC. Westem Australia 6986. They must be in double-spaced typescript on A4 sheets. All margins should be at least $30 \mathrm{~mm}$ wide. Tables plus heading and legends to illustrations should be typed on separate pages. The desired position for insertion of tables and illustrations in the text should be indicated in pencil. Tables should be numbered consecutively. have headings which make them understandable without reference to the text, and be referred to in the text.

High quality illustrations are required to size $(16.8 \mathrm{~cm} \times 25.2 \mathrm{~cm})$ or no larger than $32 \mathrm{~cm} \times 40$ $\mathrm{cm}$ with sans serif lettering suitable for reduction to size. Photographs must be good quality black and white prints, not exceeding $16.8 \mathrm{~cm} \times 25.2 \mathrm{~cm}$. Scale must be indicated on illustrations. All maps. line drawings, photographs and graphs, should be numbered in sequence and referred to as Figure/s in the text and captions. Each must have a brief, fully explanatory caption. On acceptance a computer disk containing all corrections should be sent with amended manuscript. The disk should be marked with program (e.g. Word. WordPerfect, etc).

In papers dealing with historical subjects references may be cited as footnotes. In all other papers references must be cited in the text by author and date and all must be listed alphabetically at the end of the paper. The names of journals are to be given in full.

\section{Processing:}

Papers and short communications are reviewed by at least two referees and acceptance or rejection is then decided by the editor.

The senior author is sent one set of page proofs which must be returned promptly.

The senior author will receive fifty free offprints of the paper. Additional offprints can be ordered at page proof stage. 


\section{Records of the Western Australian Museum Volume 23 Part 32007}

\section{CONTENTS}

Nadine A. Guthrie

A new species of Gnathoxys (Coleoptera: Carabidae: Carabinae) from an urban bushland remnant in Western Australia

Terry F. Houston

Observations of the biology and immature stages of the sandgroper

Cylindraustralia kochii (Saussure), with notes on some congeners

(Orthoptera: Cylindrachetidae)

Scott A. Thompson and Graham G. Thompson

Temporal variation in ground-dwelling invertebrate biomass in the

Goldfields of Western Australia

Paul Doughty and Marion Anstis

A new species of rock-dwelling hylid frog (Anura:Hylidae)

from the eastern Kimberley region of Western Australia

Marion Anstis, J. Dale Roberts and Ronald Altig

Direct development in two Myobatrachid Frogs, Arenophryne

rotunda Tyler and Myobatrachus gouldii Gray, from Western Australia

Brad Maryan, Ken P. Aplin and Mark Adams

Two new species of the Delma tincta group (Squamata: Pygopodidae)

from northwestern Australia

SHORT COMMUNICATION

Justin A. Chidlow

First record of the freshwater sawfish, Pristis microdon, from

southwestern Australian waters 